David G. Whalley MB ChB, Sawsan AlHaddad MD, Irene Khalil MD, Walter Maurer MD, Carol Furgerson MD

\title{
Metoclopramide does not decrease the incidence of nausea and vomiting after alfentanil for outpatient anaesthesia
}

\begin{abstract}
Sixty patients were studied in a randomized, double-blind manner to determine whether metoclopramide added to droperidol decreased further the incidence of emetic symptoms (nausea, retching, vomiting) in outpatients receiving alfentanil anaesthesia for nasal surgery. Group $I(n=30)$ received metoclopramide $0.15 \mathrm{mg} \cdot \mathrm{kg}^{-1}$ and Group $2(n=30)$ received placebo. In addition, both groups received droperidol 0.02 $\mathrm{mg} \cdot \mathrm{kg}^{-1}$ immediately before anaesthesia which was supplemented by alfentanil $20 \mu \mathrm{g} \cdot \mathrm{kg}^{-1}$ at induction followed by an infusion of $0.25-1 \mu \mathrm{g} \cdot \mathrm{kg}^{-1} \cdot \mathrm{min}^{-1}$. Emetic symptoms were assessed 0-3 hr, 3-6 hr and 6-24 hr after surgery. Both groups received similar doses of alfentanil (mean $\pm S D ;$ Group 14641 $\pm 1894 \mu \mathrm{g}$, Group $24714 \pm 1640 \mu \mathrm{g})$. The percentage of patients who had eigher nausea or vomiting at $0-3,3-6$ or $6-24$ hrwas $23 \%, 14 \%$ and $13 \%$ in Group 1 ; and $20 \%, 17 \%$ and $10 \%$ in Group 2. The overall incidence for each group was $8 / 30$ (27\%). There was no difference in the incidence of emetic symptoms between the groups at any time interval or throughout the study. Metoclopramide did not improve upon the antiemesis of droperidol during alfentanil anaesthesia for outpatient nasal surgery.
\end{abstract}

Soixante patients furent érudiés d'une façon randomisée à double insu afin de déterminer si la métoclopramide ajoutée au dropéridol diminue davantage l'incidence des symptômes nau-

\section{Key words}

ANAESTHETICS, INTRAVENOUS: alfentanil; SURGERY: outpatient;

VOMITING: antiemetics.

From the Department of General Ancsthesiology, The Cleveland Clinic Foundation, One Clinic Center, 9500 Euclid Ave. M26, Cleveland, Ohio 44195.

Address correspondence to: Dr. David G. Whalley.

Accepted for publication 23rd July, 1991. séux (nausée, vomissement) chez des patients externes recevam une anesthésie à l'alfentanil pour une chirurgie nasale. Le groupe I $(n=30)$ a reçu du métoclopramide $0.15 \mathrm{mg} \cdot \mathrm{kg}^{-1}$ et le groupe $2(n=30)$ a reçu du placebo. En plus, les deux groupes ont reçu du dropéridol $0,02 \mathrm{mg} \cdot \mathrm{kg}^{-1}$ immédiatement avant l'anesthésie qui fut ajouté à l'alfentanil $20 \mu \mathrm{g} \cdot \mathrm{kg}^{-l}$ lors de l'induction suivi par une perfusion de $0.25-1 \mu \mathrm{g} \cdot \mathrm{kg}^{-1} \cdot \mathrm{min}^{-1}$. Les symptômes émétiques furent évalués aux intervalles de 0-3 hres, 3-6 hres et 6-24 hres après la chirurgie. Les deux groupes ont reçu des doses similaires d'alfentanil (moyenne $\pm S D$; groupe I 464I $\pm 1894 \mu \mathrm{g}$. groupe $24714 \pm 1640 \mu \mathrm{g}$ ). Le pourcentage de patients qui ont manifesté de la nausée ou du vomissement à l'intervalle $0-3,3-6$ ou 6-24 hres était de 23\%, $14 \%$ et $13 \%$ dans le groupe 1 ; et $20 \%, 17 \%$ et $10 \%$ dans le groupe 2. L'incidence totale pour chacun des groupes était de $8 / 30$ (27\%). Il n'y avait aucune différence dans l'incidence des symptômes émétiques entre les groupes en aucun temps dans les intervalles étudiés ou à travers l'étude. La métoclopramide n'a pas amélioré l'effet antiémétique du dropéridol durant l'anesthésie à l'alfentanil pour les patients externes devant subir une chirugie nasale.

Alfentanil is a synthetic analogue of fentanyl that is more rapidly eliminated and has a shorter duration of action. ${ }^{1}$ These properties have lead to its qualified success for outpatient anaesthesia for which it has been administered either as repeated injections or as a single bolus injection followed by continuous infusion. ${ }^{2}$ Unfortunately, the advantages of this "kinetically predictable narcotic"3 have been clouded by its troublesome side-effects which include chest wall rigidity, respiratory depression and nausea and vomiting which, in some studies, has occurred in up to $60 \%$ of patients. ${ }^{2.3}$ Various antiemetics have been tried to modify this incidence but have met with only limited success due to their inefficacy and propensity to cause sedation. ${ }^{4}$ Droperidol is the antiemetic most frequently studied and its use has substantially decreased this 
TABLE I Demographic variables

\begin{tabular}{lccc}
\hline & $\begin{array}{l}\text { Group I } \\
n=30\end{array}$ & $\begin{array}{l}\text { Group 2 } \\
n=30\end{array}$ & $P$ \\
\hline Age (yr) & $49.1 \pm 15.4$ & $38.6 \pm 12.5$ & $<0.01$ \\
Weight $(\mathrm{kg})$ & $72.9 \pm 19.4$ & $73.2 \pm 14.8$ & NS \\
Height $(\mathrm{cm})$ & $170.0 \pm 10.4$ & $173.0 \pm 10.5$ & NS \\
BSA (m) & $1.68 \pm 0.41$ & $1.74 \pm 0.33$ & NS \\
Duration of surgery (min) & $89.9 \pm 25.7$ & $91.3 \pm 21.0$ & NS \\
Alfentanil $(\mu \mathrm{g})$ & $4641 \pm 1894$ & $4714 \pm 1640$ & NS \\
History of Emesis & & & \\
$\quad$ yes (\%) & $8(27)$ & $7(23)$ & NS \\
no (\%) & $22(73)$ & $23(77)$ & NS \\
Sex (M/F) & $17 / 13$ & $19 / 11$ & \\
\hline
\end{tabular}

Mean $\pm \mathrm{I} \mathrm{SD;} P>0.05=$ NS.

incidence. ${ }^{5}$ Metoclopramide, whilst ineffective when given alone during anaesthesia, ${ }^{4}$ may ameliorate further this incidence when given in combination with droperidol.

The objective of the study was to determine whether the combination of metoclopramide and droperidol was better than droperidol alone in decreasing the incidence of nausea and vomiting in patients receiving alfentanil as a supplement to oxygen/nitrous oxide/isoflurane general anaesthesia in outpatients undergoing nasal surgery.

\section{Methods}

With the approval of the Research Programs Council of the institution, 60 consenting patients undergoing nasal surgery on the day of admission were studied. The patients were randomly assigned in a double-blind manner to two groups. All patients received droperidol 0.02 $\mathrm{mg} \cdot \mathrm{kg}^{-1}$ and either metoclopramide $0.15 \mathrm{mg} \cdot \mathrm{kg}^{-1}$ in 3 $\mathrm{ml}$ solution or $3 \mathrm{ml}$ saline immediately before the induction of anaesthesia. Patients in Group $1(n=30)$ received metoclopramide and those in Group $2(n=30)$ were given the placebo. In all other respects the anaesthesia and patient management for the two groups were the same.

Anaesthesia consisted of an initial bolus of alfentanil 20 $\mu \mathrm{g} \cdot \mathrm{kg}^{-1}$ followed by a sleep dose of thiopentone $2-4$ $\mathrm{mg} \cdot \mathrm{kg}^{-1}$. Succinylcholine $1.5 \mathrm{mg} \cdot \mathrm{kg}^{-1}$ was then given to facilitate tracheal intubation. Neuromuscular function was monitored after ulnar nerve stimulation and muscle paralysis maintained with atracurium $0.5 \mathrm{mg} \cdot \mathrm{kg}^{-1}$. Anaesthesia consisted of nitrous oxide $60 \%$ in oxygen and isoflurane to a maximum end tidal concentration of $0.4 \%$, and alfentanil infused at $0.25-1 \mu \mathrm{g} \cdot \mathrm{kg}^{-1} \cdot \mathrm{min}^{-1}$. The alfentanil infusion was stopped $15 \mathrm{~min}$ before the end of the procedure. Upon completion of the surgery, the neuromuscular block was reversed with edrophonium 0.5 $\mathrm{mg} \cdot \mathrm{kg}^{-1}$ and atropine $0.015 \mathrm{mg} \cdot \mathrm{kg}^{-1}$, and the tracheal tube was removed upon the return of satisfactory respiratory function. The patient was subsequently transferred to the postanaesthesia care unit.

The incidence of emetic symptoms was determined after the method described by Hovorka. ${ }^{6}$ The patient was assessed three times: once during each of two intervals while in hospital - 0-3 hr and 3-6 hr after surgery - and again $24 \mathrm{hr}$ later by telephone. The results of the assessment were scored as: none, nausea, retching, vomiting. If the patient experienced a combination of all symptoms then he/she was listed in the most severe category. For example, if a patient experienced both nausea and vomiting, he/she was listed as having vomited. Postoperative analgesia was provided by Tylenol \#3 (acetaminophen $300 \mathrm{mg}$, codeine $30 \mathrm{mg}$; McNeil Pharmaceutical, Spring House, PA 19477) and emesis treated by a further intravenous injection of droperidol $0.625 \mathrm{mg}$.

Continuous and categorical demographic variables were analyzed using the two sample $t$ test and chi-square test respectively. The incidence of emetic symptoms was compared using an exact test for ordinal categorical data based on the Jonckheere-Terpstra test ${ }^{7}$ using the STATXact statistical software package (Citel Software Corporation, Cambridge, MA 02139). A $P$ value less than 0.05 was considered significant.

\section{Results}

The demographic variables of the two groups are presented in Table I together with the duration of surgery and the total dose of alfentanil given during the anaesthetic. The patients were comparable apart from an unexpected age difference ( $P=0.005$ ), the patients in Group 1 being on average ten years older than those in Group 2. The mean \pm SD duration of surgery was $89.9 \pm 25.7 \mathrm{~min}$ in Group 1 , and $91.3 \pm 21 \mathrm{~min}$ in Group 2. For Groups 1 and 2 respectively, the mean \pm SD total dose of alfentanil was $4641 \pm 1894 \mu \mathrm{g}\left(63.7 \pm 26 \mu \mathrm{g} \cdot \mathrm{kg}^{-1}\right) ;$ and $4714 \pm 1640$ 
TABLE II Patient medications

\begin{tabular}{lll}
\hline & $\begin{array}{l}\text { Group I } \\
n=30\end{array}$ & $\begin{array}{l}\text { Group 2 } \\
n=30\end{array}$ \\
\hline Antibiotics & 3 & 6 \\
Nasal decongestants & 9 & 4 \\
Bronchodilators & 7 & 5 \\
Corticosteroids & 7 & 4 \\
\hline
\end{tabular}

TABLE III Incidence of emesis

\begin{tabular}{lccc}
\hline & Group I & Group 2 & $P$ \\
\hline $0-3$ hr: & & & \\
None & $23(77)$ & $24(80)$ & NS \\
Nausea & $3(10)$ & $4(13)$ & \\
Vomiting & $4(13)$ & $2(7)$ & \\
$3-6$ hr: & & & \\
None & $26(87)$ & $25(83)$ & NS \\
Nausea & $2(7)$ & $2(7)$ & \\
Vomiting & $2(7)$ & $3(10)$ & \\
& & & \\
6-24 hr: & & & \\
None & $26(87)$ & $27(90)$ & NS \\
Nausea & $3(10)$ & $0(0)$ & \\
Vomiting & $1(3)$ & $3(10)$ & \\
& & & \\
$0-24$ hr worst symptom: & $22(73)$ & $22(73)$ & NS \\
None & $3(10)$ & $2(7)$ & \\
Nausca & $5(17)$ & $6(20)$ & \\
Vomiting & &
\end{tabular}

Number of patients (\%): $P>0.05=$ NS.

$\mu \mathrm{g}\left(64.4 \pm 22.4 \mu \mathrm{g} \cdot \mathrm{kg}^{-1}\right)$. Eight patients in Group 1 and seven in Group 2 gave a history of emesis during previous anaesthetics. The patients were undergoing nasal surgery - the most common procedure being a transendoscopic ethmoidectomy - and were consequently taking a variety of medications to alleviate nasal congestion. The most common medications are listed in Table II.

In Table III, the incidence of emetic symptoms is presented for both groups at each time period together with a category which tabulates the number of patients and their worst symptom throughout the study. No patient admitted to retching as a symptom and consequently that score was omitted from analysis. No difference in the incidence of emetic symptoms between the groups was found at any time interval or for the duration of the study. The percentage of patients who had either nausea or vomiting at $0-3,3-6$ or $6-24 \mathrm{hr}$ was $23 \%, 14 \%$ and $13 \%$ in Group 1; and 20\%, $17 \%$ and $10 \%$ in Group 2. Within group analysis showed no difference in the incidence at any time interval. The incidence of nausea and vomiting for the duration of the study was $27 \%$ in both Groups 1 and 2 .

Since the mean age differed between the groups the data were further examined to see if age was related to the symptoms of emesis. A one-way analysis of variance was used to compare mean age among those patients grouped according to their worst symptom of emesis. There was a trend towards those with emetic symptoms being younger, but this was not statistically significant $(P=0.16)$. Consequently, age was not adjusted for in the comparison between treatment groups.

\section{Discussion}

The study was designed to determine whether metoclopramide conferred additional antiemesis on an anaesthetic technique that already included droperidol in patients undergoing nasal surgery and receiving alfentanil. No such amelioration of emesis was demonstrated, indeed the overall incidence of nausea and vomiting in the first $24 \mathrm{hr}$ after surgery was $27 \%$ in each group.

Alfentanil has a rapid elimination and short duration of action which, despite its lesser potency than fentanyl, has made it an attractive component of a balanced technique during outpatient anaesthesia for short surgical procedures. ${ }^{1.2}$ When employing multiple boluses or an infusion of alfentanil as a supplement to anaesthesia for therapeutic abortion, it has been demonstrated that patients wake up sooner, are more quickly orientated and are ambulatory at an earlier time than when fentanyl is used. ${ }^{2}$ However, not all workers have been able to demonstrate enhanced recovery. In a similar group of patients, Cooper et al. ${ }^{8}$ did not observe differences in times to recovery of consciousness, orientation or dexterity when alfentanil was compared with fentanyl and control, although in that study considerably less narcotic was used and patient movement during anaesthesia was treated with incremental doses of methohexitone.

The incidence of nausea and vomiting after alfentanil can be substantial although not necessarily less than after fentanyl. White $e t a l^{2}$ observed nausea in $52 \%$ to $68 \%$ of their study population and vomiting in $36 \%$ to $60 \%$, with no difference between patients who had received fentanyl or alfentanil. In the study by White et al. of patients undergoing therapeutic abortion, the influence of sex and site of surgery should not be discounted as having a strong association with such a high incidence of nausea and vomiting. Recent work has emphasized the role of estrogen in the aetiology of postoperative nausea and vomiting ${ }^{9,10}$ which has been estimated to be two to three times more frequent in females than males. ${ }^{11} \mathrm{~A}$ high incidence of emesis has been noted after ear, nose and throat surgery; ${ }^{12}$ however, in the present study the influence of sex was not observed with four females and 
four males in each group suffering postoperative nausea and vomiting. A substantial decrease in the incidence of nausea and vomiting after alfentanil was reported by Jorgensen et al. ${ }^{5}$ who demonstrated that droperidol 0.02 $\mathrm{mg} \cdot \mathrm{kg}^{-1}$ reliably diminished the incidence from a control of $40 \%$ to one of $5 \%$. Patients undergoing short surgical procedures in that study were anaesthetized with oxygen, nitrous oxide and isoflurane, together with an average total alfentanil dose of greater than $5000 \mu \mathrm{g}$. Furthermore, droperidol did not appear to increase recovery time or psychomotor recovery appreciably.

Droperidol, a butyrophenone with potent antidopaminergic and neuroleptic properties is considered by many to be the prophylactic antiemetic of choice due to its demonstrable efficacy and prolonged duration of action, although a wide range of doses has been advocated. "I However, a recent dose response study of droperidol has demonstrated the superiority of droperidol $0.02 \mathrm{mg} \cdot \mathrm{kg}^{-1}$ over lesser doses after outpatient anaesthesia for laparoscopic surgery. ${ }^{13}$ After fentanyl $\mathrm{l} \mu \mathrm{g} \cdot \mathrm{kg}^{-1}$ and droperidol $0.02 \mathrm{mg} \cdot \mathrm{kg}^{-1}$, the incidence of nausea and vomiting observed by Pandit et al. was $20 \%$, which was in a similar range to that reported in the present study.

The effects of droperidol are not always favourable and the drug can be associated with disturbing extrapyramidal reactions. ${ }^{14}$ Anxiety and restlessness have recently been demonstrated in $23 \%$ of female patients undergoing a variety of minor outpatient procedures who had received droperidol $1.25 \mathrm{mg}\left(0.02 \mathrm{mg} \cdot \mathrm{kg}^{-1}\right){ }^{15}$ The patients experienced these disturbances within the $24 \mathrm{hr}$ of discharge. In the present study one patient in Group 1 and two patients in Group 2 admitted to restlessness on direct questioning which persisted for $24 \mathrm{hr}$ in one patient in Group 2.

Metoclopramide has had a checkered history as an antiemetic. It is an antidopaminergic drug with no antihistamine properties and causes little sedation in normal doses. ${ }^{16}$ In addition to its specific anti- $\mathrm{D}_{2}$ receptor activity at the chemoreceptor trigger zone, metoclopramide acts peripherally on the gastrointestinal tract by promoting faster gastric emptying and increasing lower oesophageal tone, although the mechanism of this action is not certain.

Both the route of administration and timing of the drug may be important in its success as an antiemetic. For example it may be more effective when given orally or intramuscularly ${ }^{17}$ rather than intravenously, ${ }^{18}$ suggesting that its efficacy may be related to its bioavailability and duration of action. Korttila et al. were unable to demonstrate that metoclopramide, given five minutes before the end of surgery, was any better than domperidone or saline in the prevention of postoperative nausea and vomiting. However, Doze et al. ${ }^{19}$ found that the incidence of emesis decreased from $39 \%$ to $19 \%$ when metoclopramide was added to droperidol $30 \mathrm{~min}$ before the induction of anaesthesia in patients undergoing midterm trimester abortion, raising the possibility that there may be a latency of onset of action for metoclopramide. That the timing of administration might be important for metoclopramide to be effective was not confirmed by Pandit et al..$^{13}$ who found no difference between the patients receiving metoclopramide $10 \mathrm{mg}$ and those receiving placebo $30 \mathrm{~min}$ before the induction of anesthesia for outpatient laparoscopy.

In conclusion, this study endorses the findings of those reports that were unable to demonstrate the effectiveness of metoclopramide in contributing further to the antiemesis of droperidol. Specifically, in patients receiving droperidol $0.02 \mathrm{mg} \cdot \mathrm{kg}^{-1}$ at the induction of alfentanil anaesthesia for outpatient nasal surgery, the $24 \mathrm{hr}$ incidence of nausea and vomiting was $27 \%$. This incidence was not altered by the intravenous addition of metoclopramide $0.15 \mathrm{mg} \cdot \mathrm{kg}^{-1}$.

\section{Acknowledgements}

The authors acknowledge the statistical advice of Dr. Mark Schluchter and the patient secretarial assistance of Mrs. Mary Anne Pogue.

\section{References}

1 Bovill JG, Sebel PS, Blackburn CL, Heykants J. The pharmacokinetics of alfentanil (R39209): a new opioid analgesic. Anesthesiology 1982; 57: 439-43.

2 White $P F$, Coe $V$, Shafer $A$, Sung $M$. Comparison of alfentanil with fentanyl for outpatient anesthesia. Anesthesiology 1986; 64: 99-106.

3 Stanski $D R, H u g C C$. Alfentanil - a kinetically predictable narcotic. Anesthesiology 1982; 57: 435- 8.

4 Cohen SE, Woods WA, Wyner J. Antiemetic efficacy of droperidol and metoclopramide. Anesthesiology 1984; 60: 66-9.

5 Jorgensen NH, Coyle JP. Effect of intravenous droperidol upon nausea and recovery using alfentanil anesthesia. Anesth Analg 1989; 68: S139.

6 Hovorka J, Korttila K, Erkola $O$. Nitrous oxide does not increase nausea and vomiting following gynecological laparoscopy. Can J Anaesth 1989; 36: 145-8.

7 Hollander $M$, Wolfe DA. Nonparametric Statistical Methods. Ist ed. New York: John Wiley and Sons Inc., 1973: 120-3.

8 Cooper $G, O^{\prime}$ Connor M, Mark J, Harvey J. Effect of alfentanil and fentanyl on recovery from brief anacsthesia. Br J Anaesth 1983; 55: 179-82.

9 Beattie WS, Lindblad T, Buckley DN, Forrest JB. The incidence of postoperative nausea and vomiting in women 
undergoing laparoscopy is influenced by the day of menstrual cycle. Can J Anaesth 1991; 38: 298-302.

10 Pataky AO, Kitz DS, Andrews RW, Lecky JH. Nausea and vomiting following ambulatory surgery: are all procedures created equal? Anesth Analg 1988; 67: S163.

11 Palazzo MGA, Strunin L. Review article: Anesthesia and emesis. I: Etiology. Can Anaesth Soc J 1984; 31: 178-87.

12 Haumann J, Foster $P$. The antiemetic effect of halothane. Br J Anaesth 1963; 35: 114-7.

13 Pandit SK, Kothary SP, Pandit UA, Randel G, Levy L. Dose response study of droperidol and metoclopramide as antiemetics for outpatient ancsthcsia. Anesth Analg 1989; 68: 798-802.

14 Patton CN. Rapid induction of acute dyskinesis by droperidol. Anesthesiology 1975; 43: 126-7.

15 Melnick B, Sawyer $R$, Karambelkar D, Phitayakorn $P, U y$ $N T L$, Patel $R$. Delayed side effects of droperidol after ambulatory general anesthesia. Anesth Analg 1989; 69: 748-51.

16 Pinder RM, Brogden RN, Sawyer PR, Speight TM, Avery $G S$. Metoclopramide: a revicw of its pharmacological properties and clinical use. Drugs 1976; 12: 81-131.

17 Assaff RAE, Clarke RSJ, Dundee JW. Samuel IO. Studies of drugs given before anaesthesia XXIV: metoclopramide with morphine and pethidine. Br J Anaesth 1974; 46: 514-9.

18 Korttila K, Kaust A, Auvinen J. Comparison of domperidone, droperidol and metoclopramide in prevention and treatment of nausea and vomiting after balanced anesthesia. Anesth Analg 1979; 58: 396- 400.

19 Doze VA, Shafer A, White PF. Nausea and vomiting after outpatient anesthesia: effectiveness of droperidol alone and in combination with metoclopramide. Anesth Analg 1987; 66: S41. 